\title{
ГЛУХОТА ТА ТУГОВУХІСТЬ У ДІТЕЙ: ПРИЧИНИ, ДІАГНОСТИКА, ЛІКУВАННЯ ТА ПРОФІЛАКТИКА
}

\author{
Г. М. Кожушко, О. А. Прокопович \\ Криворізький державний медичний коледж \\ Криворізька медична дитяча лікарня № 1 \\ ДВНЗ «Тернопільський державний медччний університет \\ імені І. Я. Горбачевського МОЗ Украӥни"
}

У статті проаналізовано види зниження слуху у дітей, а також методи лікування та профілактики даного захворювання.

\section{DEAFNESS AND HEARING LOSS IN CHILDREN: CAUSES, DIGNOSTIC, TREATMENT AND PREVENTION}

\author{
G. M. Kozhushko, O. A. Prokopovych \\ Kryvyi Rih Medical College \\ Kryvyi Rih Medical Children's Hospital No. 1 \\ I. Horbachevsky Ternopil State Medical University
}

The article analyzes the types of hearing loss in children, methods of treatment and prevention of this disease.

Вступ. Проблема туговухості і глухоти була та залишається актуальною як у медичному, так і соціальному відношенні. Особливо гострою є проблема дитячої глухоти, оскільки зниження слуху у віці до 2-3 років часто призводить до затримки мовного розвитку, а також несприятливо впливає на інтелектуальний та психомоторний розвиток дитини. Це ускладнює спілкування з оточуючими та ізолює її від суспільства. Слабочуюча дитина часто відстає від однолітків у розумовому розвитку, неминуче виникають труднощі у спілкуванні, виборі фаху, що вимагає від батьків значних психологічних і матеріальних зусиль. Проблема глухоти і туговухості набуває великого значення у зв'язку з їі широкою поширеністю. На сучасному етапі більше ніж у 6 \% населення є виражені порушення слуху [8].

За даними ВООЗ, від порушень слуху у світі страждає 250 млн людей. Це означає, що 4-7 \% населення страждає від порушень слухової функції (дорослих - 17,6 та дітей 1,2 на 1000 населення), а до 2020 р. число людей, які страждають від порушень слуху, збільшиться на 30 \%. Ці показники свідчать (с) Г. М. Кожушко, О. А. Прокопович, 2017 про масштаб медичної проблеми та ії соціальнопсихологічної значущості [7].

Основна частина. Під туговухістю розуміють утруднення мовного спілкування і сприйняття звуків. Розрізняють такі види туговухості: нейросенсорну, кондуктивну і змішану [6].

Нейросенсорну туговухість нерідко називають сенсоневральною. Основними причинами цієї патології $є$ інфекції, травми, хронічна недостатність мозкового кровообігу, шумовібраційний фактор, пресбіакузіс, невринома VIII нерва, радіоактивне опромінення, аномалії розвитку внутрішнього вуха, хвороби матері під час вагітності, сифіліс, інтоксикації деякими антибіотиками і медикаментами, солями важких металів (ртуті, свинцю), фосфором, миш'яком, бензином, ендокринні захворювання, зловживання алкоголем і куріння. Сенсоневральна туговухість може бути вторинною при захворюваннях, які спочатку викликають кондуктивну або змішану туговухість, а з часом призводять до функціональних і органічних змін рецепторних клітин кортієвого органу. Так відбувається при хронічному гнійному середньому отиті, адгезивному отиті, отосклерозі та хворобі Меньєра [4]. 
У 20-30 \% глухих дітей відзначають вроджену глухоту, а у 70-80 \% - порушення мозкового кровообігу, а також резус-конфлікту і гемолітичну жовтяницю.

На інфекційну природу сенсоневральної туговухості та глухоти припадає близько 30 \%. Перше місце посідають вірусні інфекції - грип, епідемічний паротит, кір, краснуха, герпеси, потім епідемічний цереброспінальний менінгіт, сифіліс, скарлатина і тифи [5].

При кондуктивній туговухості патологія виникає на рівні зовнішнього вуха (вади розвитку, сірчані пробки, пухлини, зовнішній отит), середнього вуха (травматичне ушкодження слухових кісточок і барабанної перетинки, адгезивний отит, тубоотит, отосклероз) [1].

Змішана форма характеризується наявністю як патологій звукопровідної системи, так і порушенням звукосприйняття [4].

Залежно від ступеня вираження туговухість поділяють на чотири ступені:

- 1 ступінь проявляється нездатністю чути шепіт і мову в шумному приміщенні (26-40 дБ);

- 2 ступінь встановлюють в тому випадку, якщо хворий не чує середні за гучністю звуки (40-55 дБ);

- 3 ступінь - людина насилу розрізняє звуки, в результаті чого порушується свобода спілкування (55-70 дБ);

- 4 ступінь характеризується практично повною відсутністю слуху (70-90 дБ) [3].

Залежно від часу виникнення патології розрізняють гостру, раптову і хронічну туговухість.

Для того, щоб лікування було ефективним важливо правильно діагностувати проблему. Діагностику починають з аудіометрії. Процедуру здійснює оториноларинголог. Відрізнити нейросенсорну туговухість від кондуктивної допоможе аудіограма. Крім того, під час отоскопії можуть бути виявлені рубці на барабанній перетинці, перфорації та інші дефекти.

Також для диференціальної діагностики допомагає оцінка повітряної прохідності слухового апарату. Даний процес порушується тільки при нейросенсорній туговухості. Виявити ділянку ураження допомагає отоневролог. Розрізнити види туговухості допомагає тонова аудіометрія та обстеження слухових ВП.

Важливе значення має історія розвитку захворювання, можливі причини. Саме тому фахівець повинен ретельно розпитати пацієнта і з'ясувати всі перенесені захворювання, визначити особливості праці та відпочинку.

Діагностика туговухості у дітей має певні труднощі та особливості. Найчастіше фахівці застосовують комп'ютерну аудіометрію або імпедансометрію вуха. Тільки після виявлення причини патології лікар підбирає спосіб лікування [5].

Методи лікування безпосередньо залежать від форми захворювання. Так, кондуктивна туговухість, що супроводжується порушенням функції елементів слухового апарату, вимагає хірургічного втручання. Операція полягає в мірингопластиці, тимпанопластиці або у відновленні кісточок.

При нейросенсорній туговухості порушується сприйняття звуку. Причин патології безліч, починаючи від невриту слухового нерва і закінчуючи травмами скроневої кістки. Перш ніж підбирати лікування, слід повністю обстежити хворого і виключити всі можливі провокуючі фактори.

Позбутися такого виду туговухості за допомогою операції неможливо. На ранній стадії патології найефективнішою буде медикаментозна терапія, фізіолікування і електростимуляція. Відмінно зарекомендувала себе гіпербарична оксигенація. Якщо ж захворювання прогресує або пацієнт звернувся вже на 2-3 стадії туговухості, то рекомендують підібрати апарат для корекції гостроти слуху.

Профілактика туговухості полягає у своєчасному огляді людей з високим ризиком розвитку туговухості. Обстежуються працівники хімічної промисловості та цехів із високим рівнем шуму для того, щоб вчасно виявити профзахворювання.

Особливо уважно проводять обстеження дітей, що дозволяє виявити патологію на ранній стадії розвитку. У новонароджених малюків симптоми захворювання складно виявити, тому акцентують увагу на ретельному огляді слухового проходу з використанням інструментальних методів дослідження [7].

Висновки. Враховуючи зростаючу тенденцію розвитку туговухості у дітей, медичним працівникам, а також батькам важливо своєчасно реагувати на найменші прояви втрати слуху. Своєчасний медичний огляд дозволяє виявити захворювання на ранній стадій і запобігти розвитку ускладнень захворювань слухового апарату та втраті слуху. 


\section{СПИСОК ЛІТЕРАТУРИ}

1. Дроздова М. В. Лор-заболевания : конспект лекций / М. В. Дроздова, А. А. Дроздов. - М. : Эксмо, 2007. - 160 с.

2. Мітін Ю. В. Оториноларингологія (лекції) / Ю. В. Мітін. К. : Фарм Арт, 2000. - 304 с.

3. Пальчун В. Т. Оториноларингология / В. Т. Пальчун, М. М. Магомедов, Л. А. Лучихин. - 2-е изд., испр. и доп. М. : ГЭОТАР-Медиа, 2011. - 656 с.

4. Пальчун В. Т. Оториноларингология: руководство для врачей / В. Т. Пальчун, А. И. Крюков. - М. : Медицина, 2001. - 616 c.
5. Солдатов И. Б. Лекции по оториноларингологии (учебное пособие) / И. Б. Солдатов. - М. : Медицина, 1990. - 282 c.

6. Солдатов И. Б. Оториноларингология / И. Б. Солдатов, В. Р. Гофман. - СПб. : ЭЛБИ, 2000.

7. medbib.in.ua/sensonevralnaya-tugouhost-41069.html

8. http://meduk.net.ua/archives/24399 